\title{
PENGARUH PENAMBAHAN KALIUM NITRAT DALAM LARUTAN HARA PADA MEDIA KASCING TERHADAP PERTUMBUHAN SELADA (Lactuca sativa L.)
}

\author{
HANGRIE JEMMY NAMSERNA
}

\begin{abstract}
This research was conducted with the aim to find out the effect of the addition of potassium nitrate in lettuce as a medium and critical levels of concentration(electrical conductivity)of nutrientsolution.

Research is organized in the form of a pot experiment. The experimental design used was Complete RandomizedBlock Design (CRBD)) with three replications. The treatment consists of 12 levels of concentrations or nutrient solution electrical conductivity with the addition of potassium nitrate to lettuce plant. The treatment level of concentrations (conductivity) of nutrient is as follows; $\mathrm{L} 0=0.00 ; \mathrm{L} 1=1.25$; $\mathrm{L} 2=$ $2.50 ; \mathrm{L} 3=3.75 ; \mathrm{L} 4=5.00 ; \mathrm{L} 5=6.25 ; \mathrm{L} 6=7.50 ; \mathrm{L} 7=8.75 ; \mathrm{L} 8=10.00 ; \mathrm{L} 9=11.25$; $\mathrm{L} 10=12.50$ and $\mathrm{L} 1=13,75 \mathrm{~g} 100 \mathrm{~L}-1$ water. Value concentrations of electrical conductivity each nutrient solution concentrations are: $\mathrm{L} 0=0.06 ; \mathrm{L} 1=0.26 ; \mathrm{L} 2=0.46$; $\mathrm{L} 3=0.66 ; \mathrm{L} 4=0.86 ; \mathrm{L} 5=1.06 ; \mathrm{L} 6=1.26 ; \mathrm{L} 7=1,46 ; \mathrm{L} 8=1.66 ; \mathrm{L} 9=1,86 ; \mathrm{L} 10=$ 2.06 and $\mathrm{L} 1=2.26 . \mathrm{dS} \mathrm{m}-1$.

The result of experiment showed that addition of KNO3 highly significant effect on the increasing in fresh weight and dry weight of shoot per plant. Fresh weight and oven dry weight of shoot per plant were significantly increased in a quadratic with increasing concentrations of $\mathrm{KNO}_{3}$ are optimumfor growth of plant shoot weight was at $12.23 \mathrm{~g}$ in $100 /$ of water on electrical conductivity equivalent to $2.01 \mathrm{dS} . \mathrm{m}^{-1}$. The addition of concentration of $\mathrm{KNO}_{3}$ to nutrient solution does not effect on $\mathrm{N}$ and other nutrient solution on shoot tissue of lettuce plant but the concentrations of $\mathrm{P}$ and $\mathrm{K}$ in plant shoot tissue were significantly increased linearly with the provision of $\mathrm{KNO}_{3}$.
\end{abstract}

Key words: potassium nitrate, vermicompost medium, lettuce.

\section{Latar Belakang}

Tanah tidak lagi digunakan sebagai sat-satunya media pertumbuhan tanaman dalam pot pada budidaya tanaman hortikultura karena mahalnya biaya pasteurisasi, bobotnya berat dan mudah memadat. Bahan-bahan bukan tanah berbentuk substrat padat, baik anorganik maupun organik digunakan sebagai pengganti bahan tanah untuk media pertumbuhan tanaman. Bahanbahan orgaik yang telah banyak digunakan sebagai media pertumbuhan tanaman antara lain gambut lumut (peat moss) dan arang sekam atau campuran yang tang telah memiliki dekomposisi rendah, porus dan kapasitas menahan air tinggi (Mathur dan Voisin, 1996). 
Hangrie: Pengaruh penambahan kalium nitrat dalam larutan hara pada media kascing terhadap pertumbuhan selada (Lactuca sativa L.)

Karateristik penting mediah pertumbuhan tanaman dalam budidya tanpah tanah adalah dapat menyanggah berdirinya tanaman, sebagai reservoir pasokan hara dan air, memungkinkan difusi oksigen ke akar dan memungkinkan pertukaran gas-gas antara akar dan atmosfer diluar substrat akar (Albaho et al., 2009; Atiyeh et al.,2000; Gruda, 2009; Mathur dan Voisin, 1996).

Bahan organik lain berupa kompos, baik kompos konvensional maupun kascing potensial untuk digunakan menjadi substrat alternatif karenamemiliki karakteristik yang sesuai sebagai media pertumbuhan tanaman. Kascing memiliki kandungan unsur hara, zat pengatur tumbuh, kapasitas memegang air dan kapasitas tukar kation yang lebih tinggi dibandingkan dengan kompos konvensional (Bertham, 2002; Nusantara et al.,2007). Kandungan nitrogen dan kalium dalam kascing umumnya rendah, yakni kurang dari dua persen (IPPT, 2001; Reddy dan Ohkura, 2004), sehingga masih memerlukan tambahan unsur-unsur tersebut dari sumber lain untuk memenuhi kebutuhan tanaman. Percobaan penggunaan kascing sebagai media pertumbuhan tanaman selada (Lactura sativa L.), bobot segar dan kandungan klorofil tanamn selada paling rendah pada kascing murni dibandingkan dengan tanamn pada media pertumbuhan campuran kascing dan kompos sisa-sisa tanaman (Ali et al., 2007).

Larutan hara dibuat dari berbagai bahan pupuk untuk memasok kebutuhan nitrogen dan kalium bagi tanaman dalam budidaya tanaman hortikultura dengan sistem fertigasi (sistem pemberian pupuk melalui air irigasi). Pupuk urea tidal dapat langsung menyediakan nitrogen tersedia dalam larutan hara karena masih harus melalui proses nitrifikasi terlebih dalu. Peningkatan amonium $\left(\mathrm{NH}_{4}{ }^{+}\right)$dalam larutan hara dari penambahan amonium nitrat menyebabkan terhalangnya sistem bahan kering dan serapan air, karena terhambatnya serapan kation, khususnya $\mathrm{K}^{+}$(Andriolo et al., 2006). Dibandingkan dengan kedua bahan pupuk tersebut, kalium nitrat dipandang lebih memadai karena unsur kalium dan nitrogen dalam bentuk ion-ion $\mathrm{K}^{+}$dan $\mathrm{NO}_{3}{ }^{-}$dapat langsung tersedia bagi tanaman setelah dilarutkan dalam air. 
Hangrie: Pengaruh penambahan kalium nitrat dalam larutan hara pada media kascing terhadap pertumbuhan selada (Lactuca sativa L.)

Penambahan kalium nitrat dalam larutan hara pada kascing yang digunakan sebagai media pertumbuhan tanaman dapat meningkatkan hara tersedia dan mengurangi ketidakmobilan hara dalam media pertumbuhan yang disebabkan oleh komponen-komponen media pertumbuhan. Penambahan kalium nitrat yang berlebihan dalam larutan hara juga dapat meningkatkan tekanan osmose yang mengakibatkan plasmolisis pada tanaman jika melampaui batas toleransi tanaman (De Grazia et al., 2007; Wijayani dan Widodo, 2005). Kosentrasi atau kepekatan larutan hara pada dasarnya merupakan gamabaran dari banyaknya ion atau partikel bermuatan yang alrut dalam air. Semakin tinggi kosentrasi larutan haranya, semakin cepat hantaran listriknya. Kisaran hantaran listrik yang umumnya akomidatif untuk tanaman adalah antara 2,00 - 4,00 dS.m-1 atau setara dengan kosentrasi antara 1.000 1.500 ppm. Lebih tinggi dari kosentrasi tersebut dapat mengakibatkan daun tanaman menjadi keriting dan pertumbuhan tanaman tertekan. Kisaran hantaran listrik larutan hara untuk tanaman selada terletak antara 1,0-2,8
dS.m-1 (Doorenbos dan Kassam, 1997; Wijayani dan Widodo, 2005).

Menurut Wijayani dan Widodo (2005) dan Notohadiprawiro (2006), kesulitan dalam pembuatan larutan hara adalah belum diketahui takaran unsurunsur hara yang optimal bagi serapan hara dan pertumbuhan tanaman. Penelitian mengenai kosentrasi larutan hara menggunakan ukuran hantaran listrik akan sangat membantu menentukan takaran unsur-unsur hara yang ditambahkan kedalam larutan hara. Tingkat hantaran listrik dapat menjadi petunjuk batas kosentrasi larutan hara yang masih aman bagi tanaman. Informasi mengenai takaran kalium nitrat yang dapat ditambahkan berdasarkan ukuran hantaran listrik akan sangat membantu menentukan takaran unsur-unsur hara yang ditambahkan kedalam larutan hara. Tingkat hantaran listrik dapat menjadi petunjuk batas kosentrasi larutan hara yang masih aman bagi tanaman. Informasi mengenai takaran kalium nitrat yang dapat ditambahkan berdasarkan ukuran hantara listrik bagi tanaman selada belum banyak dipublikasikan. Hal ini mendasari perlunya dilakukan penelitian mengenai 
Hangrie: Pengaruh penambahan kalium nitrat dalam larutan hara pada media kascing terhadap pertumbuhan selada (Lactuca sativa L.)

takaran penambahan kalium nitrat ke dalam larutan menggunakan ukuran hantaran listrik hingga mencapai kosentrasi yang masih aman bagi tanaman selada.

Keberhasilan pengembangan hortikultura ditentukan oleh kecanggihan dan kelengkapan komponen teknologi yang dirakit dalam sistem budidayanya. Hortikultura mengandung banyak komponen teknologi berupa rekayasa rumah kaca dan media pertumbuhan (Notohadiprawiro, 2006). Penggunaan media pertumbuhan bukan tanah yang disesuaikan dengan syarat kebutuhan tiap jenis tanaman dalam budidaya tanaman dalam budidaya tanaman hortikultura telah banyak dilakukan sebagai pengganti media pertumbuhan berbahan tanah.

\section{Metode Penelitan}

\section{Rancangan Penelitan}

Penelitian ini diselenggarakan dalam bentuk percobaan pot. Rancangan percobaan yang digunakan adalah rancangan acak kelompok lengkap (RAKL) dengan tiga ulangan. Perlakun terdiri dari 12 tingkat kosentrasi larutan hara yang diukur dalam hantaran listrik (electrika conduktivit $=\mathrm{EC}$ ) dengan penambahan kalium nitrat ke dalam larutan hara.

Perlakuan tingkat kosentrasi (hantaran listrik) larutan hara adalah sebagi berikut; $\mathrm{L} 0=0,00 ; \mathrm{L} 1=1,25$; L2 = 2,50; L3 = 3,75; L4 = 5,00; L5 = 6,25; L6 = 7,50; L7 = 8,75; L8 = 10,00; $\mathrm{L} 9=11,25 ; \mathrm{L} 10=12,50$ dan $\mathrm{L} 11=13$, 75 g.100 L-1 air. Nilai kosentrasi hantaran listrik masing-masing kosentrasi larutan hara adalah: $\mathrm{L} 0=0,06$; $\mathrm{L} 1=0,26 ; \mathrm{L} 2=0,46 ; \mathrm{L} 3=0,66 ; \mathrm{L} 4=0,86$; L5=1,06; L6=1,26; L7=1,46; L8=1,66; L9=1,86; L10=2,06 dan $\mathrm{L} 11=2,26$ dS.m-1.

\section{Lokasi dan waktu penelitian}

Penelitian dilakukan dalam rumah plastik di Ubung, Denpasar Barat. Penelitian berlangsung selama 30 (tiga puluh) hari, yaitu sejak 28 oktober hingga 30 november 2010.

\section{Variabel penelitian}

Variabel pengamatan dalam percobaan meliputi; pertumbuhan tanaman, kandungan hara makro dan mikro dalam trubus tanaman dan analisis kandungan kimia kascing.

\section{Bahan dan alat penelitian}

Percobaan menggunakan benih selada keriting varieta Lologreen. Bahan pupuk mineral. 
Hangrie: Pengaruh penambahan kalium nitrat dalam larutan hara pada media kascing terhadap pertumbuhan selada (Lactuca sativa L.)

Peralatan penelitian meliputi: pot PVC berdiameter $10 \mathrm{~cm}$, pompa air selam (submersible pump) dengan kapasitas tekanan (head) 3,0 meter, regulator, EC meter, $\mathrm{pH}$ meter, wadah larutam nutrisi berkapsitas 60 liter, pipa PVC 0,5 inci, pipa PE $4 \mathrm{~mm}$, regulating stik, timbangan top loader dan oven pengering, serta kabel, isolator dan konektor untuk instalasi jaringan listrik.

\section{Analisis data}

Hasil pengukuran setiap variabel pertumbuhan tanaman dianalisis menggunakan analisis ragam. Dua individu tanaman diambil sebagai tanaman contoh, kemudian hasil pengukuran dirata-ratakan.

\section{Hasil dan pembahasan}

\section{Berat trubus tanaman}

Hasil percobaan menunjukan bahwa pemberian kosentrasi kalium nitrat $\left(\mathrm{KNO}_{3}\right)$ berpengaruh sangat nyata terhadap peningkatan berat segar dan berat kering trubus per tanaman.semua perlakuan kosentrasi $\mathrm{KNO}_{3}$ memberi pengaruh yang berbeda nyata terhadap berat segar maupun berat kering trubus per tanaman dibandingkan dengan kontrol. Berat segar dan berat kering trubus per tanaman paling tinggi diperoleh pada pemberian $\mathrm{KNO}_{3}$ dengan kosentrasi 12,50 g.100 $\mathrm{L}^{-1}$ dan berbeda nyata dengan berat segar dan berat kering trubus per tanaman pada perlakuan kosentrasi $\mathrm{KNO}_{3}$ lainnya.

Berat kering trubus tanaman tidak berbeda nyata dengan peningkatan kosentrasi $\mathrm{KNO}_{3}$ hingga 2,50 g.100 $\mathrm{L}^{-1}$. Berat kering trubus tanaman juga tidak berbeda nyata dengan peningkatan kosentrasi $\mathrm{KNO}_{3}$ dari 3,75 hingga 11,25 g.100L-1. Berat kering trubus tanaman juga menurun secara nyata dengan peningkatan kosentrasi $\mathrm{KNO}_{3}$ dari 12,50 menjadi 13,75 g. $100 \mathrm{~L}^{-1}$.

Berat segar dan berat kering trubus per tanaman meningkat sangat nyata secara kuadratik dengan peningkatan kosentrasi $\mathrm{KNO}_{3}$. Besarnya kontribusi pengaruh kosentrasi $\mathrm{KNO}_{3}$ terhadap peningkatan berat segar trubus tanamn lebih besar dibandingkan terhadap berat kering trubus tanaman yaitu masing-masing $88,90 \%$ dan $58,90 \%$.

Berdasarkan persamaan regresi, diketahui bahwa berat segar dan berat kering trubus tanaman maksimum per tanaman yaitu masing-masing 57,92 g dan 2,56 g. Berat segar dan berat kering trubus tanaman maksimum dicapai pada pemberian kosentrasi $\mathrm{KNO}_{3}$ antara 
Hangrie: Pengaruh penambahan kalium nitrat dalam larutan hara pada media kascing terhadap pertumbuhan selada (Lactuca sativa L.)

11,25 dan 12,50 g. $100 \mathrm{~L}^{-1}$ air. Berdasarkan pencapaian berat maksimum trubus tanaman, maka pemberian kosentrasi $\mathrm{KNO}_{3}$ yang optimum bagi pertumbuhan berat trubus tanamn adalah pada kosentrasi 12,23 g.100 $\mathrm{L}^{-1}$ air atau setara dengan hantaran listrik 2,01 dS.m-1.

Kosentrasi hara dalam jaringan trubus

Berdasarkan hasil analisis kimia dalam jaringan trubus tanaman selada diketahui bahwa peninkatan kosentrasi $\mathrm{KNO}_{3}$ dalam larutan hara tidak berpengaruh terhadap kosentrasi hara makro $\mathrm{N}, \mathrm{Ca}, \mathrm{Mg}, \mathrm{S}$ dan $\mathrm{Na}$ dalam jaringan trubus tanaman. Kosentrasi $\mathrm{P}$ dan $\mathrm{K}$ dalam jaringan trubus tanaman meningkat sangat nyata secara linier dengan pemberian kosentrasi $\mathrm{KNO}_{3}$ dalam larutan hara. Kosentrasi Fe, Mn, $\mathrm{Al}$ dan $\mathrm{B}$ dalam jaringa trubus tanaman meningkat secara kuadratik tidak nyata dengan pemberian kosentrasi $\mathrm{KNO}_{3}$ dalam larutan hara tidak berpengaruh terhadap kosentrasi $\mathrm{Cu}$ dan $\mathrm{Zn}$ dalam jaringan trubus tanaman.

Berat segar trubus per tanamanberkrelasi sangat nyata dengan kosentrasi $\mathrm{P}$ dan $\mathrm{K}$ dalam jaringan trubus, yakni masing-masing dengan nilai r 0,747 dan 0,744. Berat kering trubus per tanaman berkorelasi nyata dengan kosentrasi $\mathrm{P}$, tetapi berkorelasi tidak nyata dengan kosentrasi $\mathrm{K}$ kani masing-masing dengan nilai $r$ 0,613 dan 0,570 .

Bebrapa parameter kimia dalam kascing yang digunakan sebagai media pertumbuhan yang diukur setelah percobaan, secara kuantitas mengalami peningkatan maupun penurunan. Parameter-parameter kimia dalam media pertumbuhan yang mengalami peningkatan adalah $\mathrm{pH}$, kadar air, $\mathrm{P}_{2} \mathrm{O}_{5}$, $\mathrm{CaO}, \mathrm{MgO}, \mathrm{S}, \mathrm{Fe}, \mathrm{Al}, \mathrm{Cu}, \mathrm{Zn}$, dan $\mathrm{B}$, sedangkan parameter kimia yang mengalami penurunan adalah nisba $\mathrm{C} / \mathrm{N}$. Walaupun terjadi peningkatan kosentrasi unsur-unsur kimia dalam media pertumbuhan, namun peningkatan kosentrasi unsur-unsur kimia tersebut bukan dipengaruhi oleh pemberian $\mathrm{KNO}_{3}$ dalam larutan hara.

\section{Pembahasan}

Adanya pengaruh yang nyata secara statistik dari pemberian kosentrasi kalim nitrat $\left(\mathrm{KNO}_{3}\right)$ terhadap berat segar dan bbberat kering trubus tanaman selada, serta diperolehnya kosentrrrasi $\mathrm{KNO}_{3}$ optimum antara 12,23 g. $100 \mathrm{~L}^{-1}$ atau hantaran listrik 
Hangrie: Pengaruh penambahan kalium nitrat dalam larutan hara pada media kascing terhadap pertumbuhan selada (Lactuca sativa L.)

larutan hara 2,01 dS.m-1 untuk mencapai berat trubus maksimum tanaman selada, maka kedua hipotesis penelitian, yakni penambahan $\mathrm{KNO}_{3}$ dalam larutan hara dapat meningkatkan pertumbuhan tanaman selada dan batas kritis kosentrasi larutan hara daripenambahan kalium nitrat terhadap tanaman selada tidak lebih dari 12,50 g. $100 \mathrm{~L}^{-1}$ air dalam percobaan ini diterima.

Peningkatan barat segar maupun berat kering trubus per tanaman dengan peningkatan kosentrasi $\mathrm{KNO}_{3}$ dalam larutan hara menunjukan adanya peningkatan massa yang nyata dalam tanaman terkait dengan aktivitas fotosintesis tanaman. Buwalda dan Warmenhoven (1999) dari hasil percobaannya pada tanaman selada menyatakan bahwa kosentrasi nitrat dalam trubus berkorelasi positif dengan laju pertumbuhan relarif tanaman. Nitrat dan senyawa karbohidrat not-struktural terlarut dalam sel-sel jaringan tanaman berperan penting dalam mempertahankan tugor sel pada tanaman selada, sehingga luas permukaan daun dapat tetap dipertahankan bagi kelangsungan aktivitas fotosintesis yang stabil.
Peningkatan berat trubus tanaman selada dalam penelitian ini dengan peningkatan kosentrasi $\mathrm{KNO}_{3}$ dalam larutan hara dapat menjadi petunjuk bahwa pemakaian kascing sebagai media pertumbuhan tanaman selada masih memerlukan penambahan unsur hara $\mathrm{N}$ dan $\mathrm{K}$. Meninhkatnya kosentrasi $\mathrm{KNO}_{3}$ dalam larutan hara tidak berpengaruh terhadap peningkatan ksentrasi $\mathrm{N}$ dalam jaringan trubus tanaman selada. Dengan demikian, tidak ada hubungan antara peningkatan berat trubus dengan kosntrasi $\mathrm{N}$ dalam jaringn trubus tanaman selada. Tidak meningkatnya kosentrasi $\mathrm{N}$ dalam jaringan trubus tanaman selada juga diperoleh Burdine et al (1976) dan Sanches et al. (1988) pada percobaan pemberian takaran $\mathrm{N}$ hingga $200 \mathrm{~kg} \mathrm{~N}$ ha sekalipun respon hasil tanamn selada meningkat nyata secara kuadratik. Menurut Blair (1975), nitrogen adalah unsur yang sangat mobil didalam tanaman, yang berarti bahwa senyawaan fungsional yang mengandung $\mathrm{N}$ yang terdapat didalam jaringan dapat dipecah atau dirombak untuk kemudian dipindahkan kebagian jaringan yang aktif tumbuh. Protei sel-sel vegetatif sebagian besar bersifat fungsional dan 
Hangrie: Pengaruh penambahan kalium nitrat dalam larutan hara pada media kascing terhadap pertumbuhan selada (Lactuca sativa L.)

hanya sebagian kecil yang bersifat srtuktural yang tidak stabil yang terusmenerus dipecah dan dibentuk kembali. Dalam penelitian ini tidak dianalisis kandungan nitrat dalam jaringan trubus tanaman. Menurut Lastra et al. (2009), akumulasi nitrat dalam tanamn selada terkait dengan karakteristik faktor genetika, pemupukan nitrogen dan proses-proses residu enzimatik nitrat di dalam tanaman.

Faktor lain yang dapat diduga dari tidak berkorelasinya antar berat trubus dan kosentrasi $\mathrm{N}$ dalam jaringan trubus adalah karena seluru bahan media pertumbuhan mengguanakan kascing dengan bahan dasar campuran kotoran sapi dan limbah pertanian. Sekalipun peningkatan pemberian kosentrasi $\mathrm{KNO}_{3}$ secara sangat nyata meningkatkan berat trubus tanaman selada dalam penelitian ini masih jauh lebih rendah dibandingkan dengan ratarata berat normal trubus tanaman selada pada umur tanaman yang sama, kani sekitar $200 \mathrm{~g}$ per tanaman. Menurut Atiyeh et al. (2000), struktur fisik kascing murni yang berasal dari kotoran sapi tidak menguntungkan bagi pertumbuhan tanaman jika digunakan sebagai media pertumbuhan. Arancon et al. (2004) dalam pengujian kascing terhadap pertumbuhan dan hasil cabai merah memperoleh bahwa peningkatan $\mathrm{N}$ biomassa mikroba tidak berkorelasi dengan hasil. Semakin tinggi kandungan kascing dalam campuran media pertumbuhan $(60-100 \%)$ hasil tanaman menurun secara nyata. Keadaan tersebut dapat disebabkan karena tingginya kosentrasi garamgaram terlarut, aerasi yang buruk, toksisitas logam berat dan atau fitotoksisitas yang terdapat didalam kascing. Selama percobaan ini, aktivitas cacing tanah yang terdapat dalam media pertumbuhan menyebabkan kondisi aerasi dan drainasi media pertumbuhan memburuk, sehingga sistem perlindian larutan hara terhambat.

Meningkatnya kosentrasi P dan K dalam jaringan trubus yang sangat nyata secara linear, menunjukan bahwa kosentrasi $\mathrm{P}$ dan $\mathrm{K}$ belum mencapai kosentrasi kritis dalam jaringan trubus tanaman selada. Meningkatnya kosentrasi $\mathrm{P}$ dalam jaringan trubus diduga karena meningkatnya ketersediaan $\mathrm{P}$ dalam media pertumbuhan dari hasil proses meneralisasi bahan-bahan organik, sehingga serapan $\mathrm{P}$ oleh tanaman juga 
Hangrie: Pengaruh penambahan kalium nitrat dalam larutan hara pada media kascing terhadap pertumbuhan selada (Lactuca sativa L.)

meningkat. Hasil analisis kimia kascing setelah percobaan menunjukan bahwa kosentrasi $\mathrm{P}$ meningkat dibandingkan dengan sebelim percobaan. Meningkatnya kosentrasi P karena proses meneralisasi dan mobilitas $\mathrm{P}$ dari aktivitas bakteri dan aktivitas fosfatase ekskresi cacing tanah (Chaudhuri et al. (2000). Meningkatnya berat trubus dala percobaan ini diduga karena lebih tingginya asimilasi, translokasi dan penggunaan fosfor. Fosfor (P) merupakan unsur esensial dalam proses fotosintesis dan respirasi maupun pembentkan metabolik melalui transport energi sebagai ATP dan NADPH (Filho et al., 2009).

Meningkatnya kosetrasi $\mathrm{Fe}, \mathrm{Al}$, Mn dan B dalam jaringan trubus tanaman selain dapat disebabkan adanya pengaruh tidak langsung dari peingkatan kosentrasi $\mathrm{KNO}_{3}$, juga oleh meningkatnya unsur-unsur mikro dalam kascing, diduga karena masih berlangsungnya aktivitas penghancuran dan mineralisasi bahan-bahan organik kascing oleh cacing tanah dan mikroorganisme. masih berlangsungnya aktivitas penghancuran dan mineralisasi tersebut menunjukan bahwa bahan kascing yang digunakan sebagai media pertumbuhan belum terdekomposisi sempurna, sehingga proses pelepasan unsur-unsur mikro oleh mikroorganisme dalam media tumbuh masih terus berlangsung selama waktu percobaan. Nisbah $\mathrm{C} / \mathrm{N}$ bahan organik digunakan sebagai indikator kematangan kompos dan untuk memprediksi laju mineralisasi bahan organik. Lebih rendahnya nilai $\mathrm{C} / \mathrm{N}$ sebelum percobaan, menunjukan bahwa proses dekomposisi bahan organik masih berlangsung selama percobaan. Pelepasan sebagian karbon $\mathrm{CO}_{2}$ karena proses respirasi dan produksi nitrogen dari mineralisasi kandungan $\mathrm{N}$ dalam kascing menyebabkan nisbahC/N menurun.

\section{Kesimpulan}

1. Pemberian $\mathrm{KNO}_{3}$ dalam larutan memberikan pengaruh yang nyata terhadap barat segar dan berat kering trubus tanaman selada. Berat segar dan berat kering trubus tanaman selada meningkat sangat nyata secara kuadratik dengan meningkatnya kosentrasi $\mathrm{KNO}_{3}$ dalam larutan hara.

2. Kosentrasi $\mathrm{KNO}_{3}$ yang optimum bagi pertumbuhan berat trubus tanaman selada terletak pada kosentrasi 12,23 
Hangrie: Pengaruh penambahan kalium nitrat dalam larutan hara pada media kascing terhadap pertumbuhan selada (Lactuca sativa L.)

g.100 $\mathrm{L}^{-1}$ air atau setara dengan hantara listrik 2,01 dS.m-1.

3. Peningkatan kosentrasi $\mathrm{KNO}_{3}$ dalam larutan hara tidak mempengaruhi kosentrasi $\mathrm{N}$ dan unsur hara lainnya dalam jaringan trubus tanaman selada, tetapi kosentrasi $\mathrm{P}$ dan $\mathrm{K}$ meningkat sangat nyata secara linear.

\section{Ucapan Terima Kasih}

Pada kesempatan ini penulis ingin mengucapkan terima kasih kepada semua pihak yang telah membantu dengan caranya masing-masing dalam melengkapi tulisan ini.

\section{Daftar Pustaka}

Aalok, A., Tripathi, A. K., Soni, P. 2008. Vermicomposting: A Better Option For Organik Solid Waste Management. J. Hum. Ecol.24 (1): 59-64.

Ali, M., Griffiths, A J,. Wiliams, K. P Jones, D.L. 2007. Evaluating the growth charateristics of lettuce in vermicompost and green waste compost. Euro. J. Solid biol. 43;s316-S319.

Andrilo, N. Q. Edwars, C A Atiyeh, R., Metzger, J.D 2004. Effeck of vermicomposts Produced from Food Waste on the growt and Yields of green house pappers. Bioresource teknology 93:139-144

Aracon, N Q,. Edward C. A Atiyeh, R., Metzger. J.D. 2004 Effeck of vermicomposts Produced from Food Waste on the growt and Yields of green house pappers. Bioresource teknology 93:139-144

Atmojo, S.W. 2003. Peranan bahan organik terhadap kesuburan tanah dan upaya pengelolaannya. Surakarta. Sebelas Maret University Press.

Bertham, Rr. Y.H. 2002. Potensi pupuk hayati dalam peningkatan produktivitas kacang tanah dan kacang kedelai pada tanah seri kandanglimun bengkulu. JIIPI 4 (1): 18-26

Mathur, S. P., voisin, B . 1996. The use of compost as greenhouse growth media. Final Report. Ontario. Ministry of Enviropment and Energy. 18p.

Notohardiprawiro, T. 2006. Konsep sempit lingkungan pertanian kendala berat bagi pembangunan nasional. J.Ilmu tanah dan lingkungan 6 (1): 63-70

De Grazia, J., Tittonell, P A., Chiesa, A. 2007. The effect of substrates with compost and nitrogenous fertilazation on photosyntesis, precocity and pepper (Capsicum annum) yield. Cien.Inv. Agr.34 (3): 151-160. 